\title{
A Study About Menstrual Personal Hygiene Knowledge and Behavior Among Adolescence School Girl in Jombang
}

\author{
Eka Tyas As Sidiqiah ${ }^{1}$ Siti Nurrochmah ${ }^{2, *}$ Farah Paramita $^{1}$ \\ ${ }^{1}$ Department of Public Health, Faculty of Sport Sciences, Universitas Negeri Malang, Malang, East Java, Indonesia \\ ${ }^{2}$ Department of Physical Education, Health, and Recreation, Faculty of Sport Sciences, Universitas Negeri Malang, \\ Malang, East Java, Indonesia \\ *Corresponding author. Email: siti.nurrochmah.fik@um.ac.id
}

\begin{abstract}
Sexual and reproductive health education is still considered taboo to be given to teenagers, so there are still many myths and bad perceptions related to menstruation. Preliminary studies show that there was 6 out of 10 students had poor menstrual personal hygiene. Self-care during menstruation can be influenced by various factors, including biological, cultural, environmental, social values, knowledge and perceptions. This study aims to determine the relationship between menstrual personal hygiene knowledge and attitudes of among adolescence school girl in Jombang. The design of this study was analytic observational with cross-sectional approach. The research population was 1.374 adolesence school girl in Jombang from one of senior high school, with a total sample of 95 respondents who were taken using the quota sampling technique. Data was collected by distributing online questionnaires using Google forms. The result showed that the majority (76\%) of respondents had high level of knowledge and $77 \%$ respondents show good menstrual personal hygiene behavior. Chi-square test showed that there was a significant relationship between knowledge and menstrual personal hygiene behavior ( $\mathrm{p}$-value 0.037). The conclusion of the study was that the most adolescence school girl in Jombang already had good knowledge and behavior about menstrual personal hygiene.
\end{abstract}

Keywords: menstrual personal hygiene, knowledge, adolescent girl.

\section{INTRODUCTION}

Sexual and reproductive health education is often considered taboo to be given to adolescents, while growth and development in adolescents take place relatively quickly both physically and mentally so that they can carry out their functions. reproduction process [1], [2]. According to WHO and the Indonesian Minister of Health, adolescents are residents with an age range of 1019 years and the BKKBN states that the age range of adolescents is 10-24 years and is not married. Around $18 \%$ or 1.2 billion people of the world's total population are controlled by teenagers aged 10-19 years and in Indonesia teenagers are the largest group, which is around 45.3 million or $17 \%$ of the total population[3], [4]. The number of teenagers in East Java is recorded at 6.1 million people or about $15.65 \%$ of the total population of East Java. According to age group, the largest number is in early adolescence (11-15 years) as many as $49.77 \%$, middle adolescents (16-18 years) as much as $30.36 \%$ and late adolescence (18-19 years) with $19,87 \%$ [5]. According to data from the BPS of Jombang Regency (2019: 64), adolescents aged 10-14 years amounted to 108,909 people, while adolescents in the 15 19 year age group were 109,206 people [6].

One of the signs of puberty that marks the transition period of a woman from childhood to adulthood is the arrival of menstruation due to the shedding of the uterine wall (endometrium) which has thickened after 14 days of ovulation due to the absence of fertilization of the egg by sperm[7], [8]. Referring to the 2017 Indonesian Adolescent Reproductive Health Demographic Survey data, it is known that $26 \%$ of women experienced menarche at the age of 12 years, $28 \%$ at the age of 13 years and $23 \%$ at the age of 14 years [9]. Interestingly, there is a fact that female respondents experience their first menstruation at the age of 10-11 years by $9 \%$, along with the growth and development of adolescents, it is feared that it can cause various opportunities and risks of disruption or problems in their reproductive health, such 
as Reproductive Tract Infections (RTI), Sexually Transmitted Infections (STI) and HIV-AIDS [10].

In 2016, WHO stated that the number of new cases of Reproductive Tract Infections (RTI) reached more than 1 million cases every day, thus accounting for more than 376 million new cases every year. The adolescent age group is the highest contributor to Reproductive Tract Infection (RTI) cases in the world, namely $35-42 \%$ and $27-33 \%$ in early adulthood [11]. Reproductive Tract Infections (RTI) are caused by organisms that normally live or enter the reproductive tract or due to poor medical and personal hygiene procedures such as the use of unclean menstrual pads, sexual hygiene and poor vaginal hygiene [12].

Indonesia as one of the tropical countries in Southeast Asia, makes the body more susceptible to sweating and makes the closed and folded areas of the body including the reproductive organs more humid, so that it can trigger the onset of RTI. Data obtained from the BPS and Bappenas in 2010 showed that the majority of Indonesian youth, which reached 63 million people, were vulnerable to unhealthy behavior regarding the hygiene conditions of the reproductive organs during menstruation [13], [14]. According to the 2015 BKKBN data, adolescents are at very high risk for reproductive health disorders because knowledge about the function and how to care for the reproductive organs is still very low at only $19.5 \%$ [15].

Germs in the form of fungi, bacteria, parasites and viruses can make the vagina susceptible to infection due to the very narrow boundary between the urethra and anus making it easy to enter the vaginal canal [16]. One of the efforts to prevent disease or disorders during menstruation is to get used to hygienic behavior or health efforts to maintain one's cleanliness and health during menstruation [16]. One of the behaviors that are lacking in menstrual hygiene care is not washing hands before and after changing pads and the frequency of changing pads [16]. Self-care during menstruation can be influenced by various factors, including biology, culture, environment, social values, knowledge and perceptions of self-care [16], [17].

There are still many spread of bad perceptions and myths related to menstruation among the community due to the lack of knowledge and insight in the community so that a make-up mindset arises [8]. Knowledge is an important domain for forming actions (overt behavior) that will last longer, compared to actions that are not based on knowledge [18]. This vaginal infection every year affects women worldwide, almost $10-15 \%$ of 100 million women can be caused by improper care for the external genitalia [19]. Adolescents who have an understanding of menstrual personal hygiene will tend to have the awareness to take positive actions when they are menstruating [16], [18], [20]. Therefore, young women need to get reproductive health education as early as possible, one of which is related to menstrual personal hygiene. This is so that adolescents have the correct knowledge for preparation as adults and are expected to be responsible for decisions in making attitudes and behavior related to self-care during menstruation [2], [13].

Based on the premilinary studies, it is known that 5 out of 10 students still use cloth sanitary napkins during menstruation. And 6 out of 10 students are known behavior personal hygiene to have bad, namely being lazy to change sanitary napkins. In addition, the frequency of learning and extracurricular activities lasts longer from morning to evening, followed by recitation activities in the evening. This will affect the behavior personal hygiene of adolescent girls during menstruation, such as the frequency of changing sanitary napkins only once a day. However, young women should equip themselves from home to behave properly during menstruation wherever they are. Based on the results of research conducted by Winerungan, Esther and Ferdinand in 2013 in the city of Manado, stated that young women who have knowledge related to personal hygiene during menstruation with good categories amounted to 14 respondents $(8.4 \%)$, only 74 respondents $(44.3 \%)$ and the poor category amounted to 79 respondents (47.3\%) [21]. From the background of the problems described above and referring to the results of interviews and supported by the results of previous studies, the researchers were interested in studying the relationship between menstrual personal hygiene knowledge and behavior among adolescence school girl in Jombang.

\section{METHOD}

This study is a quantitative study with an analytical observational design using approach cross-sectional. This research was conducted at one of Senior High School in Jombang from April to May 2021. The population of the study was 1374 adolescence school girl in jombang and 95 was recruited as respondent. The sampling technique used is quota sampling that meets the inclusion criteria: 1) Students who are willing to participate in the study and fill out informed consent, 2) Students who have experienced menstruation, 3) Students who are 17 years old, 4) Students who have good internet access and the exclusion criteria: 1) Students who have not experienced menstruation, 2) Students who cannot fill out the questionnaire form because of poor internet access.

This research data collection was carried out by distributing questionnaires in the online form of Google forms via WhatsApp for each class group to obtain primary data obtained directly from respondents. The results of the research data obtained were then analyzed by univariate and bivariate analysis using the statistical Chi-square test to see if there was a relationship between knowledge and menstrual personal hygiene behavior. 
This research has passed the ethical review and received approval from the Health Research Ethics Commission of the Health Polytechnic of the Ministry of Health of Malang with the number 045/KEPK-POLKESMA/2021.

\section{RESULTS}

The results of the research analyzed by univariate and bivariate are presented in the following table:

\subsection{Characteristics of Respondents}

Table 1. Characteristics of Respondents

\begin{tabular}{|l|l|c|c|}
\hline Category & Sub Category & n & \% \\
\hline \multirow{3}{*}{ Age } & 17 years & 66 & 69 \\
\cline { 2 - 4 } & 18 years & 20 & 21 \\
\cline { 2 - 4 } & 19 years & 9 & 9 \\
\hline \multirow{2}{*}{$\begin{array}{l}\text { Age of } \\
\text { menarche }\end{array}$} & $<12$ years & 10 & 11 \\
\cline { 2 - 4 } & $12-13$ years & 49 & 52 \\
\cline { 2 - 4 } & $\geq 14$ years & 36 & 38 \\
\hline $\begin{array}{l}\text { Menstrual } \\
\text { hygiene } \\
\text { materials }\end{array}$ & $\begin{array}{l}\text { Disposable sanitary } \\
\text { pad }\end{array}$ & 77 & 81 \\
\cline { 2 - 4 } & Reusable pad & 18 & 19 \\
\hline
\end{tabular}

Based on table 1 , shows that by age category the majority of respondents are 17 years old, as many as 66 respondents $(69 \%), 18$ years old as many as 20 respondents (21\%) and at least 19 years old as many as 9 respondents $(9 \%)$. Characteristics of respondents based on the age category of menarche (the age of first menstruation) the majority of respondents aged 12-13 years as many as 49 respondents (52\%), 14 years as many as 36 respondents $(38 \%)$ and at least $<12$ years old as many as 10 respondents $(11 \%)$. Characteristics of respondents based on the menstrual hygiene material, the majority of respondents used disposable sanitary pad as many as 77 respondents $(81 \%)$ and at least reusable pad as many as 18 respondents $(19 \%)$.

\subsection{Knowledge of Menstrual Personal Hygiene}

Table 2. Knowledge of Menstrual Personal Hygiene

\begin{tabular}{|c|c|c|c|}
\hline Category & Sub Category & n & \% \\
\hline Knowledge & High & 72 & 76 \\
\cline { 2 - 4 } & Low & 23 & 24 \\
\hline
\end{tabular}

Based on Table 2. above illustrates that the respondents' knowledge of menstrual personal hygiene is majority have a high level of knowledge as many as 72 respondents $(76 \%)$ and a low level of knowledge as many as 23 respondents $(24 \%)$.

\subsection{Behavior of Menstrual Personal Hygiene}

Table 3. Behavior of Menstrual Personal Hygiene

\begin{tabular}{|c|c|c|c|}
\hline Category & $\begin{array}{c}\text { Sub } \\
\text { Category }\end{array}$ & $\mathbf{n}$ & \% \\
\hline $\begin{array}{c}\text { Behavior of } \\
\text { Menstrual Personal } \\
\text { Hygiene }\end{array}$ & Good & 73 & 77 \\
\cline { 2 - 4 } & Poor & 22 & 23 \\
\hline
\end{tabular}

Characteristics of respondents in Table 3. the above illustrates that the behavior of menstrual personal hygiene the majority of respondents has a menstrual behaviors personal hygiene good as much as 73 respondents $(77 \%)$ and conduct menstrual personal hygiene poor as many as 22 respondents $(23 \%)$.

\subsection{Relationship Between Knowledge and Behavior of Menstrual Personal Hygiene}

Table 4. Relationship Between Knowledge and Behavior of Menstrual Personal Hygiene

\begin{tabular}{|c|c|c|c|c|}
\hline \multirow[t]{2}{*}{ Knowledge } & \multicolumn{2}{|c|}{$\begin{array}{c}\text { Behavior of } \\
\text { Menstrual Personal } \\
\text { Hygiene }\end{array}$} & \multirow[t]{2}{*}{ Total } & \multirow[t]{2}{*}{$p$-value } \\
\hline & Good & Poor & & \\
\hline \multirow[t]{2}{*}{ Good } & 59 & 13 & 72 & \multirow[t]{6}{*}{0.037} \\
\hline & $62.1 \%$ & $13.7 \%$ & 75.8 & \\
\hline \multirow[t]{2}{*}{ Poor } & 14 & 9 & 23 & \\
\hline & $14.7 \%$ & $9.5 \%$ & 24.2 & \\
\hline \multirow[t]{2}{*}{ Total } & 73 & 22 & 95 & \\
\hline & $76.8 \%$ & $23.2 \%$ & $\begin{array}{c}100 \\
\%\end{array}$ & \\
\hline
\end{tabular}

The results of bivariate analysis using the Chi-square test in the study obtained p-value $0.037<0.05(\alpha)$, it can be concluded that there is a relationship between knowledge and behavior of menstrual personal hygiene.

\section{DISCUSSION}

\subsection{Knowledge of Menstrual Personal Hygiene}

The results showed that the majority of research respondents had a high level of knowledge as many as 72 people $(76 \%)$ about menstrual personal hygiene. The results of this study were supported by Sukyati's research (2019) which stated that the majority of respondents had high knowledge of 84 respondents (84\%) and a few respondents who have low knowledge of 16 respondents regarding personal hygiene during menstruation (16\%) [22]. Knowledge of menstrual personal hygiene is important for adolescent girls to maintain individual hygiene and health during menstruation to achieve physical and psychological well-being and improve one's health status [17].

Mubarak (2012: 83-84), states that many factors can affect a person's knowledge, namely age, interests, experience, education, environment, culture and information [23]. Knowledge is the result of knowing that occurs after someone makes senses usually through the eyes and ears of a particular object. The sensing will leave an impression in the human mind based on the experience gained by every human being [18], [23]. The high knowledge of respondents in this study means that after observing what the respondent has seen or it can be interpreted that he knows about menstrual personal hygiene is good, so that it leaves an impression of the experience he has seen with five senses [24]. 


\subsection{Behavior of Menstrual Personal Hygiene}

The results showed that the majority of research respondents had behavior menstrual personal hygiene good as many as 73 respondents $(77 \%)$. The results of this study are supported by Andani (2019) in his research which states that the majority of respondents have good behavior on menstrual personal hygiene as many as 62 people $(79.5 \%)$ and a few respondents who have behavior menstrual personal hygiene bad as many as 16 people (20.5\%) [25]. Menstrual personal hygiene is a sympathetic, emotional and hygiene care during menstruation mainly related to the genital area, sanitary napkins, personal hygiene, diet and exercise [26].

A person's behavior can be formed through the stages of the process of change from knowledge (know), attitude (attitude) and behavior (practice). Adolescent knowledge about reproductive health problems will affect their attitude, if they have good knowledge they will form a good attitude as well. Someone who already has good knowledge and attitude can direct someone's behavior to good things and vice versa [27], [28]. Lack of knowledge and attitudes about menstrual personal hygiene makes it difficult to implement preventive behavior towards reproductive health disorders. The application of menstrual personal hygiene that is lacking will facilitate the emergence of reproductive health disorders [29].

\subsection{Relationship Between Knowledge and Behavior of Menstrual Personal Hygiene}

The results of bivariate analysis obtained p-value $0.037<0.05(\alpha)$, it can be concluded that there is a relationship between knowledge and behavior of menstrual personal hygiene. Menstrual personal hygiene is an individual effort to maintain individual hygiene and health which is carried out during the menstrual period to obtain physical and psychological well-being and improve one's health status [17], [26]. Many factors can affect personal hygiene during menstruation, including knowledge related to reproductive health and personal hygiene in women, both during menstruation and in daily life [30]. Knowledge is the result of individual understanding after sensing a certain object, and becomes an important domain for forming one's actions (overt behavior). Actions or behaviors will last a long time if they are based on knowledge compared to actions or behaviors that are not based on knowledge [18].

The results of this study are supported by the research of Wahyudi, et al. (2018) conducted on 117 female students at MI Miftahul Ulum Pamekasan who stated that the knowledge possessed by the respondents had a relationship with behavior as menstrual personal hygiene evidenced by the p-value of $0.001<0.05(\alpha)$ [30]. A teenager who already has good knowledge regarding hygiene related to menstrual personal hygiene will encourage himself to behave healthily during menstruation because he realizes the importance of trying to maintain cleanliness during menstruation [31]. Mubarak (2012: 83-84), suggests that a person's knowledge is influenced by many factors, namely interests, age, experience, information, education, environment and culture [23].

The results of this study indicate that the level of knowledge of respondents is high and behavior menstrual personal hygiene is good for 59 respondents (62.1\%). Researchers assume that respondents have high knowledge along with easily obtaining information in the digital era, in addition to respondents being able to obtain information from mothers, peers, teachers and health workers, respondents can also obtain information from social media such as Facebook, Instagram and others. Increasing one's knowledge can change one's perceptions and behavior from negative to positive, these perceptions can come from internal stimuli such as curiosity that arises about something so that someone wants to find out the truth [32], [33]. In addition, this perception can also arise due to stimuli from outside a person, such as the individual participating in health education activities or counseling by health workers, education personnel and others. Perceptions that arise from both inside and outside a person are expected to be able to obtain correct and accountable information, so that the individual will have a good stock of knowledge to behave positively as well [32]. The easier it is for teenagers to get the right information, the more knowledge they will have and they will tend to behave well [34].

In the study there were 14 respondents $(14.7 \%)$ with low knowledge group accompanied by behavior menstrual personal hygiene good, researchers assumed that this behavior could not just happen. Changing behavior or adopting new behavior requires a process starting from a change in knowledge (knowledge) attitude (attitude) - behavior (practice) or KAP. However, this cannot always be proven, in everyday behavior the opposite can happen, namely where a person already has positive behavior even though his knowledge or attitude is still negative [18]. Hosland, et al. (1953) in Notoatmodjo (2012: 200), says that behavior is essentially the same as the learning process, it can make individuals understand the positive or negative impact of behavior related to the state of menstruation they experience, as well as a teenager who previously had the behavior menstrual personal hygiene is bad and causes health problems for him. The teenager finally learns from the experience that occurred due to behavior that harmed him before, so that in the future he will avoid this bad behavior and change it for the better [18].

\section{CONCLUSION}

Based on the research that has been presented, it can be concluded that there is a significant relationship between knowledge and behavior menstrual personal hygiene among adolescent school girls in Jombang 
statistical analysis using Chi-square test was obtained pvalue of $0.037>0.05(\alpha)$.

\section{AUTHORS' CONTRIBUTIONS}

ETA contributed in concept and design study, methodology, data collection, data analysis, and write the manuscript. SN and FP contributed in validation, supervision, and write the review and edit.

\section{ACKNOWLEDGMENTS}

The authors thank to all respondents that participated in this study and also Faculty of Sport Sciences, Universitas Negeri Malang for the support.

\section{REFERENCES}

[1] I. Prijatni and S. Rahayu, Modul Bahan Ajar Cetak Kebidanan: Kesehatan Reproduksi dan Keluarga Berencana. Jakarta: Pusat Pendidikan Sumber Daya Manusia Kesehatan, 2016.

[2] A. Riyadi, Pemenuhan Hak Kesehatan Seksual dan Reproduksi (Annual Report 2015). Jakarta: PKBI, 2016.

[3] Badan Pusat Statistik (BPS), Statistik Indonesia 2020. Jakarta: Badan Pusat Statistik, 2020. [Online]. Available:

https://www.bps.go.id/publication/2020/04/29/e901 1b3155d45d70823c141f/statistik-indonesia2020.html

[4] Kementerian Kesehatan RI, Infodatin Kesehatan Reproduksi Remaja. Pusat Data dan Informasi Kementerian Kesehatan RI, 2015. [Online]. Available:

https://pusdatin.kemkes.go.id/download.php?file=d ownload/pusdatin/infodatin/infodatin-reproduksiremaja.pdf

[5] Badan Pusat Statistika (BPS) Provinsi Jawa Timur, Statistik Remaja Jawa Timur 2015. Surabaya: Badan Pusat Statistik Provinsi Jawa Timur, 2016. [Online]. Available: https://jatim.bps.go.id/publication/2016/06/30/d1fa c45b25821d9a73e967c2/statistik-remaja-jawatimur-2015.html

[6] Badan Pusat Statistika (BPS) Kabupaten Jombang, Kabupaten Jombang Dalam Angka 2019. Jombang: Badan Pusat Statistika (BPS) Kabupaten Jombang, 2019. [Online]. Available: https://jombangkab.bps.go.id/publication/2019/08/ 16/13ed62a0f2f7470798e508f1/kabupatenjombang-dalam-angka-2019.html

[7] R. D. Pudiastuti, Tiga Fase Penting Pada Wanita. Jakarta: PT Elex Media Komputindo, 2012.
[8] E. Sinaga et al., Manajemen Kesehatan Menstruasi. Jakarta: Universitas Nasional IWWASH Global One, 2017. [Online]. Available: http://ppi.unas.ac.id/wpcontent/uploads/2017/06/Buku-ManajemenKesehatan-Menstruasi-Oke.pdf

[9] Badan Kependudukan dan Keluarga Berencana Nasional (BKKBN), Badan Pusat Statistik (BPS), Kementerian Kesehatan RI (Kemenkes RI), and ICF International, Survei Demografi dan Kesehatan Remaja Indonesia 2017. Jakarta: BKKBN, BPS, Kemenkes RI dan ICF International, 2018. [Online]. Available: https://promkes.net/2018/10/19/laporansdki-tahun-2017-kesehatan-reproduksi-remaja/

[10] Y. Harnani, H. Marlina, and E. Kursani, Teori Kesehatan Reproduksi (Untuk Mahasiswa Ilmu Kesehatan Masyarakat). Sleman: Deepublish, 2015.

[11] WHO, Report On Global Sexually Transmitted Infections Surveillance 2018. Geneva: WHO, 2018. [Online]. Available: https://apps.who.int/iris/bitstream/handle/10665/27 7258/9789241565691-eng.pdf?ua=1

[12] P. Sharma and P. Sheoran, "Screening and Assessment of Knowledge and Expressed Practices Regarding Reproductive Tract Infection among Married and Unmarried Women in Rural Area of Mullana, Ambala, Haryana," Int. J. Sci. Res. IJSR, vol. 4, no. 2, pp. 465-470, 2015.

[13] K. Irianto, Panduan Lengkap Biologi Reproduksi Manusia (Human Reproductive Biology) Untuk Paramedis dan Nonmedis. Bandung: Alfabeta, 2014.

[14] G. C. T. Pawesti, "Pengaruh Metode Multimedia Learning Tentang Perineal Hygiene Terhadap Pengetahuan Dan Sikap Pada Remaja Putri Yang Mengalami Menstruasi di SMP PGRI 1 Pakisaji Kabupaten Malang," University Muhammadiyah Malang, 2015. [Online]. Available: http://eprints.umm.ac.id/23543/1/jiptummpp-gdlgitacitrat-40027-2-bab1.pdf

[15] Ernawati, A. Asrina, and Suharni, "Pengaruh Metode Diskusi Terhadap Pengetahuan Dan Sikap Tentang Kebersihan Diri (Studi Pada Santriwati Pondok Pesantren Darul Abrar)," Semin. Nas. Sinergitas Multidisiplin Ilmu Pengetah. Dan Teknol. SMIPT, vol. 2, pp. 48-53, 2019.

[16] Hastuti, R. K. Dewi, and R. P. Pramana, Studi Kasus Manajemen Kebersihan Menstruasi (MKM) Siswa SD dan SMP di Indonesia. Jakarta: The SMERU Research Institute, 2019. [Online]. Available: http://www.smeru.or.id/sites/default/files/publicati on/mkm_id_0.pdf 
[17] L. A. Kristanti and C. Y. Sebtalesy, Kapasitas Orang Tua Terhadap Personal Hygiene Anak Autis. Ponorogo: Uwais Inspirasi Indonesia, 2019.

[18] S. Notoatmodjo, Promosi Kesehatan dan Perilaku Kesehatan. Jakarta: PT. Rineka Cipta., 2012.

[19] N. A. Putri and A. Setianingsih, "Hubungan Pengetahuan dan Sikap Terhadap Perilaku Personal hygiene Mentruasi," J. Ilmu Kesehat. Masy., vol. 5, no. 1, pp. 62-76, 2016, doi: 10.33221/jikm.v5i1.310.

[20] T. D. Palupi, T. Y. R. Pristya, and R. Novirsa, "Myths About Menstrual Personal Hygiene Among Female Adolescents," J. Kesehat. Masy. Nas. Natl. Public Health J., vol. 15, no. 2, pp. 80-85, 2020, doi: 10.21109/kesmas.v15i2.2719.

[21] E. M. Winerungan, E. Hutagaol, and F. Wowiling, "Hubungan Pengetahuan Kesehatan Reproduksi Dengan Kejadian Iritasi Vagina Saat Menstruasi Pada Remaja di SMP Negeri 8 Manado," $J$. Keperawatan, vol. 1, no. 1, Art. no. 1, Aug. 2013.

[22] I. Sukyati, “Analysis Of Factors Affecting Young Women Attitudes Toward Female Hygiene And Perineal Hygiene Behavior," Pros. 3rd Int. Nurs. Conf. 2019, vol. 1, no. 1, pp. 13-21, 2019.

[23] Mubarak, Promosi Kesehatan Untuk Kebidanan. Jakarta: Salemba Medika, 2012.

[24] Neubrina Raseuky Sukamto, Yulia Farida Yahya, Dwi Handayani, Fifa Argentina, and Iche Andriyani Liberty, "Hubungan Pengetahuan, Sikap dan Perilaku Perawatan Vagina Terhadap Kejadian Keputihan Patologis Pada Mahasiswi Program Studi Pendidikan Dokter Fakultas Kedokteran Universitas Sriwijaya," Maj. Kedokt. Sriwij., vol. 50, no. 4, pp. 113-122, 2018, doi: https://doi.org/10.36706/mks.v50i4.8571.

[25] P. R. Andani, "Correlation Between Knowledge And Attitude Toward Personal Menstrual Hygiene Practice Among Adolescents," JPH RECODE, vol. 4, no. 2, pp. 88-98, 2019, doi: http://dx.doi.org/10.20473/jphrecode.v4i2.14460.

[26] I. Clement, Manual of Community Health Nursing. New Delhi: Jaypee Brothers Medical Publishers, 2012.

[27] K. C. Pythagoras, "Personal Hygiene Remaja Putri Ketika Menstruasi," J. Promkes, vol. 5, no. 1, pp. 13-26, 2017, doi: http://dx.doi.org/10.20473/jpk.V5.I1.2017.13-26.

[28] Kiswanto, H. E. Wardani, and A. Hapsari, "Hubungan Pengetahuan dengan Mitra Pria dalam Keluarga Berencana di Desa Klampok, Kecamatan
Singosari, Kabupaten Malang," Sport Sci. Health, vol. 1, no. 1, pp. 10-13, 2019.

[29] I. A. Jasmine, L. Rosida, and L. Marlinae, "Hubungan Antara Pengetahuan dan Sikap Tentang Personal Higiene dengan Perilaku Pencegahan Penularan Skabies," J. Publ. Kesehat. Masy. Indones., vol. 3, no. 1, pp. 7-12, 2016, doi: http://dx.doi.org/10.20527/jpkmi.v3i1.2730.

[30] A. S. Wahyudi, C. P. Asmoro, and I. Suarilah, "Faktor Yang Berhubungan Dengan Personal Hygiene Saat Menstruasi," J. Kesehat. Manarang, vol. 4, no. 2, pp. 104-113, 2018, doi: https://doi.org/10.33490/jkm.v4i2.96.

[31] M. A. C. Ningrum and D. R. Indriyanti, "The Influence of Knowledge, Attitude, Family Support and Peer Support on The Behavior of Female Teenage Menstrual Hygiene," Public Health Perspect. J., vol. 3, no. 2, pp. 99-107, 2018.

[32] H. A. Nur, "Hubungan Persepsi, Sikap dan Perilaku Remaja Putri Tentang Personal Hygien Genitalia dengan Kejadian Fluor Albus (Keputihan)," J. Profesi Keperawatan, vol. 5, no. 1, pp. 1-13, 2018.

[33] Nessi Meilan and Desy Rizka Wanti, "Pengetahuan Remaja Kelas VII Tentang Personal hygiene Saat Menstruasi di SMPN 31 Kota Bekasi Tahun 2018," 2-TRIK Tunas-Tunas Ris. Kesehat., vol. 9, no. 3, pp. 249-254, 2019, doi: http://dx.doi.org/10.33846/2trik9310.

[34] M. Y. Wardhani, H. E. Wardani, and A. Hapsari, "Hubungan Antara Kunjungan Antenatal Care (ANC) dengan Pengetahuan tentang Tanda Bahaya Nifas pada Ibu Nifas," Sport Sci. Health, vol. 1, no. 3, pp. 193-197, 2019 